\title{
OPTIMALISASI INTEGRASI KEBIJAKAN PENGGUNAAN SARANA PENAL DAN NON PENAL DALAM UPAYA PENANGGULANGAN TINDAK PIDANA NARKOBA OLEH KEPOLISIAN RESOR DEMAK
}

\author{
Saroni, Hidayatullah dan Iskandar Wibawa
}

Email : roni12323@yahoo.com, hidayatullah@umk.ac.id, iskandar.wibawa@yahoo.com

Fakultas Hukum Universitas Muria Kudus

\begin{abstract}
ABSTRAK
Peredaran narkoba yang makin beredar luas di kalangan masyarakat Kabupaten Demak, mulai dari orang tua, remaja, bahkan pelajar semakin meresahkan. Hal tersebut membuat Satresnarkoba Polres Demak harus bergerak cepat untuk menanggulanginya. Oleh karena itu, Satresnarkoba Polres Demak menggunakan integrasi kebijakaan penggunaan sarana penal dan non penal. Sarana penal dilakukan melalui jalur hokum pidana, sedangkan sarana non penal dilakukan sebagai pencegahan. Sedangkan integrasi kebijakan dilakukan dengan menggabungkan kedua sarana tersebut.
\end{abstract}

Kata Kunci : Kebijakan Integral, Sarana Penal, Sarana Non Penal, Narkotika 


\section{PENDAHULUAN}

Fenomena Kabupaten Demak yang banyak industi bermunculan disana memberikan dampak pada sosial ekonomi dan budaya masyarakat Kabupaten Demak. Tindakan dan penanggulangan narkoba yang dilakukan oleh Polres Demak pada hakikatnya telah digariskan dalam suatu bentuk kebijakan yang selaras dengan karakter masyarakat wilayah Demak. Dengan kata lain, walaupun telah ada akses perundang-undangan yang mengatur penanganan narkoba dari pemerintah pusat, dalam pelaksanaannya Polres Demak harus pula mengatur kebijakan sendiri dalam penanganannya. Kebijakan adalah suatu kecerdikan, kepintaran, garis haluan, rangkaian konsep dan asas yang menjadi garis besar dan rencana dalam pelaksanaan suatu pekerjaan dan kepemimpinan, terutama pada pemerintahan, organisasi, dan sebagainya. $^{23}$

Wilayah Kabupaten Demak terbagi dalam 14 kecamatan yang terdiri dari 243 desa dan 6 kelurahan, 512 dusun, 6.326 Rukun Tetangga (RT) dan 1.262 Rukun Warga (RW). Peredaran Narkotika di Kabupaten Demak kebanyakaan diperoleh dari Semarang yang ditarik ke Demak, dan kebayakan TKP di Demak mayoritas di Mranggen selebihnya di Sayung, Karangawen, Guntur, Karang Tengah dan Demak kota sendiri. Ada beberapa kasus yang sudah ditangani di Kepolisian Resor Demak sebagai berikut.

\footnotetext{
${ }^{23}$ Peter dan Yenny, Kamus Bahasa Indonesia Kontemporer, Modern English Press, Jakarta, 2011, halaman. 42.
}

Tabe1 .1

Data Ungkap Kasus Kepolisian Resor Demak Tahun 2016 - 2017

\begin{tabular}{|l|l|c|}
\hline No & \multicolumn{1}{|c|}{ Jenis Kasus } & \multicolumn{1}{|c|}{$\begin{array}{c}\text { Kasus yang } \\
\text { Ditangani }\end{array}$} \\
\hline 1 & $\begin{array}{l}\text { Tahun 2016 } \\
\text { Narkotika } \\
\text { UU. No. 35 } \\
\text { Tahun 2009 } \\
\text { Obat-Obatan } \\
\text { UU. No. 36 } \\
\text { Tahun 2009 } \\
\text { Miras }\end{array}$ & 28 Kasus \\
\hline 2 & $\begin{array}{l}\text { Tahun 2017 Kasus } \\
\text { Narkotika } \\
\text { UU No. 35 Th } \\
\text { 2009 } \\
\text { Obat Terlarang } \\
\text { UU No. 36 } \\
\text { tentang } \\
\text { Kesehatan }\end{array}$ & 25 Kasus \\
\hline
\end{tabular}

Sumber : Kepolisian Resor Demak, 2017.

Menyadari bahwa ancaman bahaya yang ditimbulkan akibat dari penyalahgunaan narkotika dan psikotropika yang telah meresahkan masyarakat, maka untuk itu dilakukan upaya penanggulangan dengan mengunakan sarana penal maupun sarana non penal. Kedua sarana ini (penal dan non penal) merupakan suatu pasangan yang satu sama lain tidak dapat dipisahkan, bahkan dapat dikatakan keduanya saling melengkapi dalam usaha penanggulangan kejahatan tindak narkoba di masyarakat. ${ }^{24}$ Pencegahan dan pemberantasan penyalahgunaan narkotika atau psikotropika harus dilakukan

\footnotetext{
${ }^{24}$ Dwidja Priyanto, Sistem Pelaksanaan Pidana Penjara di Indonesia, Refika Aditama, 2006, Bandung, hlm.61
} 
pendekatan integral yaitu antara sarana penal dan non penal.

Pencegahan dan pemberantasan penyalahgunaan narkotika atau psikotropika harus dilakukan dengan metode pendekatan integral yaitu antara perpaduan antara sarana penal dan sarana non penal. Mengingat bahwa keberhasilan-keberhasilan atas penanganan kasus narkoba yang dilakukan oleh Kepolisian Resor Demak selalu dihadapkan pada fenomena-fenomena baru seiring dengan terjadinya berbagai perubahan pola kehidupan sosial budaya masyarakatnya, maka persoalan inilah yang selanjutnya dijadikan tumpuan perumusan masalah penelitian. Karena itu upaya pemberantasan dan penanggulangan terhadap tindak pidana narkoba di wilayah hukum Kepolisian Resor Demak selanjutnya akan dijadikan pijakan penelitian ini. Berdasarkan Latar Belakang di atas maka penulis tertarik mengambil judul "Optimalisasi Integrasi Kebijakan Penggunaan Sarana Penal dan Non Penal dalam Upaya Penanggulangan Tindak Pidana Narkoba oleh Kepolisian Resor Demak." Permasalahan yang akan diteliti yaitu :

1. Bagaimana integrasi kebijakan penggunaan sarana penal dan non penal dalam menanggulangi tindak-pidana narkoba di Kepolisian Resor Demak?

2. Bagaimana kendala dan upaya pada penerapan kebijakan penal dan non penal dalam pencegahan kejahatan narkoba di Kabupaten Demak?

\section{METODE PENELITIAN}

Penelitian ini termasuk dalam penelitian deskriptif (descripteive research) yaitu penelitian untuk eksplorasi dan klarifikasi mengenai fenomena atau kejadian sosial. ${ }^{25}$ Penelitian yuridis sosiologis atau penelitian yuridis empiris menurut sifatnya merupakan penelitian yang bersifat deskriptif yaitu penelitian yang dimaksudkan untuk memberikan data yang seteliti mungkin tentang manusia, keadaan atau gejala-gejala lain. ${ }^{26}$

Data yang akan dikumpulkan meliputi data primer dan data sekunder terhadap pokok permasalahan penelitian. Metode penelitian menggunakan metode studi kepustakaan dan wawancara dengan pihak yang terkait dengan permasalahan penelitian. Setelah semua data terkumpul, dilanjutkan dengan langkah analisis data. Analisis data bertujuan untuk menemukan jawaban atas perumusan masalah sebagaimana yang telah ditetapkan. ${ }^{27}$ Mengingat persoalan yang diajukan dalam penelitian ini bersifat tinjauan atas tindakan kebijakan maka digunakan teknik analisis data kualitatif. Dengan kata lain, data tidak bersifat angka ataupun diangkakan untuk statistik, tetapi bentuknya merupakan informasi naratif. Karena itu sasarannya tidak mementingkan banyaknya data, tetapi yang diutamakan detail dan kerinciannya.

\footnotetext{
25 Setiono, Rule of Law (Supremasi Hukum), Magister Ilmu Hukum Program Pascasarjana Universitas Sebelas Maret, 2015, Surakarta, hlm. 21

26 Soerjono Soekanto, 2016, Pengantar Penelitian Hukum, UI Press, Jakarta, hlm.4

${ }^{27}$ H. Zainuddin Ali, Metode Penelitian hukum, Sinar Grafika, 2010, Jakarta, hlm.17
} 


\section{HASIL PENELITIAN DAN PEMBAHASAN}

\section{Integrasi Kebijakan Penggunaan Sarana Penal dan Non Penal Dalam Menanggulangi Tindak Pidana Narkoba}

Kabupaten Demak adalah salah satu Kabupaten di Jawa Tengah yang terletak pada 6043'26" - 709'43" LS dan $110^{\circ} 48^{\prime} 47^{\prime \prime}$ BT dan terletak sekitar $25 \mathrm{~km}$ di sebelah timur Kota Semarang. Demak dilalui jalan negara (pantura) yang menghubungkan JakartaSemarang-Surabaya-Banyuwangi.

Kabupaten Demak memiliki luas wilayah seluas $\pm 1.149,07 \mathrm{~km}^{2}$, yang terdiri dari daratan seluas \pm $897,43 \mathrm{~km}^{2}$, dan lautan seluas \pm $252,34 \mathrm{~km}^{2}$. Sedangkan kondisi tekstur tanahnya, wilayah Kabupaten Demak terdiri atas tekstur tanah halus (lanau) dan tekstur tanah sedang (lempung). Dilihat dari sudut kemiringan tanah, rata-rata datar. Dengan ketinggian permukaan tanah dari permukaan air laut (sudut elevasi) wilayah kabupaten Demak terletak mulai dari $0 \mathrm{~m}$ sampai dengan $100 \mathrm{~m}$.

Kabupaten Demak terdiri atas 14 kecamatan yaitu Kecamatan Demak, Wonosalam, Karangtengah, Bonang, Wedung, Mijen, Karanganyar, Gajah, Dempet, Guntur, Sayung, Mranggen, Karangawen dan Kebonagung, yang dibagi lagi atas sejumlah 249 desa dan kelurahan terdiri dari 243 desa dan 6 kelurahan. Pusat pemerintahan berada di Kecamatan Demak.

Sumber Daya Manusia Satres Narkoba Polres Demak terdiri dari 14 anggota. Dalam melaksanakan tugasnya, Satresnarkoba bertugas melaksanakan pembinaan fungsi penyelidikan, penyidikan, pengawasan penyidikan tindak pidana penyalahgunaan dan peredaran gelap Narkoba berikut prekursornya, serta pembinaan dan penyuluhan dalam rangka pencegahan dan rehabilitasi korban penyalahgunaan Narkoba.

Dalam melaksanakan tugas sebagaimana dimaksud diatas, Satresnarkoba Polres Demak menyelenggarakan fungsi sebagai berikut :

1. penyelidikan dan penyidikan tindak pidana penyalahgunaan dan peredaran gelap Narkoba, dan prekursor;

2. pembinaan dan penyuluhan dalam rangka pencegahan dan rehabilitasi korban penyalahgunaan Narkoba;

3. pengawasan terhadap pelaksanaan penyelidikan dan penyidikan tindak pidana penyalahgunan Narkoba yang dilakukan oleh unit reskrim Polsek dan Satresnarkoba Polres; dan

4. penganalisisan kasus beserta penanganannya, serta mengkaji efektivitas pelaksanaan tugas

Satresnarkoba dipimpin oleh Kasatresnarkoba yang bertanggung jawab kepada Kapolres dan dalam pelaksanaan tugas sehari-hari di bawah kendali Wakapolres. Dalam melaksanakan tugas, Satresnarkoba dibantu oleh:

1. Urusan Pembinaan Operasional (Urbinopsnal), yang bertugas melakukan pembinaan dan pengawasan terhadap administrasi serta pelaksanaan penyelidikan dan penyidikan tindak pidana Narkoba, pembinaan dan penyuluhan dalam rangka pencegahan dan rehabilitasi korban penyalahgunaan Narkoba serta menganalisis penanganan 
kasus dan mengevaluasi efektivitas pelaksanaan tugas Satresnarkoba;

2. Urusan Administrasi dan Ketatausahaan (Urmintu), yang bertugas menyelenggarakan kegiatan administrasi dan ketatausahaan; dan

3. Unit, terdiri dari paling banyak 3 (tiga) Unit, yang bertugas melakukan penyelidikan dan penyidikan tindak pidana penyalahgunaan dan peredaran gelap Narkoba dan prekursor di daerah hukum Polres Demak.

\section{Kebijakan Penal Dalam Menanggulangi Tindak Pidana Narkoba}

Rekapitulasi kejadian pada tahun 2015, 2016 dan 2017 yaitu sebagai berikut :

- Januari tahun 20152 kasus, tahun 20161 kasus, tahun 20170 kasus;

- Februari tahun 20151 kasus, tahun 20162 kasus, tahun 20171 kasus;

- Maret tahun 20150 kasus, tahun 20164 kasus, tahun 20172 kasus;

- April tahun 20150 kasus, tahun 20166 kasus, tahun 20171 kasus;

- Mei tahun 20150 kasus, tahun 20160 kasus, tahun 20170 kasus;

- Juni tahun 20158 kasus, tahun 20165 kasus, tahun 20171 kasus;

- Juli tahun 20153 kasus, tahun 20164 kasus, tahun 20172 kasus;

- Agustus tahun 20150 kasus, tahun 20161 kasus, tahun 20173 kasus;

- September tahun 20152 kasus, tahun 20162 kasus, tahun 20170 kasus;

- Oktober tahun 20150 kasus, tahun 20160 kasus, tahun 20173 kasus;

- November tahun 20154 kasus, tahun 20164 kasus, tahun 20171 kasus;
- Desember tahun 20150 kasus, tahun 20160 kasus, tahun 20170 kasus.

Dari data tersebut di atas dapat dilihat bahwa terjadi peningkatan signifikan khususnya ungkap kasus narkotika dari tahun 2015 sebanyak 20 kasus dan pada tahun 2016 mengalami kenaikan menjadi 30 kasus (naik 50\%) dan pada tahun 2017 mengalami kenaikan menjadi 37 kasus (naik 23\%).

Adanya kenaikan tersebut dipengaruhi oleh kesadaran masyarakat yang minim khususnya generasi muda (pelajar dan mahasiswa) akan narkotika beserta bahayanya yang bersifat adiktif. Ketidaktahuan ini mengakibatkan persebaran narkotika menjadi meluas.

Disamping itu faktor lain yang menyebabkan kenaikan dari tahun ke tahun adalah semakin canggihnya cara pengedar dalam menyelundupkan dan mengedarkan barang tersebut kepada pengguna. Oleh karena itu Satres Narkoba Polres Demak bekerja sama dengan pihak bea cukai untuk terus mengawasi peredaran barang illegal. Utamanya didaerah yang dekat dengan perbatasan.

Tabel 1

Data Tempat Kejadian Tindak Pidana Narkotika Tahun 2017 Polres Demak

\begin{tabular}{|l|l|c|}
\hline No & Tempat Kejadian & $\begin{array}{c}\text { Jumlah } \\
\text { Kejadian }\end{array}$ \\
\hline 1. & Demak & 3 \\
\hline 2. & Karangawen & 6 \\
\hline 3. & Mranggen & 19 \\
\hline 4. & Sayung & 5 \\
\hline 5. & Guntur & 2 \\
\hline 6. & Wonosalam & 1 \\
\hline 7. & Karangtengah & 1 \\
\hline 8. & Mijen & 0 \\
\hline 9. & Wedung & 0 \\
\hline 10. & Bonang & 0 \\
\hline
\end{tabular}




\begin{tabular}{|c|l|c|}
\hline 11. & Karanganyar & 0 \\
\hline 12. & Gajah & 0 \\
\hline 13. & Dempet & 0 \\
\hline 14. & Kebonagung & 0 \\
\hline & JUMLAH & 37 \\
\hline
\end{tabular}

Sumber: Resor Demak, 2018.

Dari tabel di atas dapat disimpulkan bahwa kejadian narkotika selama tahun 2017 Kec. Mranggen menduduki peringkat pertama disusul dengan Kecamatan Karangawen dan Sayung.

\section{Kebijakan Non Penal Dalam Menanggulangi Tindak Pidana Narkoba}

Dengan telah meningkatnya kejadian Narkotika yang mengalami kenaikan setiap tahun, Polres Demak mengadakan terobosan pemasangan spanduk tentang himbauan bahaya penyalahgunaan narkotika dan mengadakan penyuluhan dengan dasar:

a. Undang-undang Nomor 2 Tahun 2002, tentang Kepolisian Negara Republik Indonesia;

b. Undang-undang Nomor 35 Tahun 2009 tentang Narkotika;

c. Undang Undang Nomor 36 Tahun 2009 tentang Kesehatan;

d. Rencana Kerja Polres Demak TA 2017;

e. Rencana Kegiatan Satresnarkoba TA 2017;

f. Koordinasi secara lisan

Dalam rangka terwujudnya kesadaran masyarakat yang anti narkoba di wilayah Kabupaten Demak, dan kesadaran hukum dan kepatuhan hukum serta memelihara Kamtibmas dilingkungan masyarakat untuk meningkatkan peran serta masyarakat dan instansi untuk menciptakan situasi dan kondisi yang kondusif. Perkembangan situasi yang menuntut agar masyarakat lebih mengerti dalam menyikapi perkembangan situasi di maksud.

Sementara itu, maksud dilaksanakan kegiatan pembinaan dan penyuluhan pencegahan penyalahgunaan narkoba kepada masyarakat, mahasiswa dan pelajar yang ada di wilayah hukum Polres Demak adalah agar subjek kegiatan mengetahui tentang bahaya penyalahgunaan narkoba, serta memelihara keamanan dan ketertiban masyarakat yang kondusif tanpa narkoba.

\section{Kebijakan Integral Dalam Menanggulangi Tindak Pidana Narkoba}

Optimalisasi Integrasi kebijakan penggunaan sarana penal dan non penan dalam mencegah tindak pidana narkoba juga dilakukan oleh Kepolisian Resor Demak. Upaya yang dilakukan untuk pencegahan tentang peredaran narkoba di wilayah hukum Polres Demak Satresnarkoba bekerjasama dengan :

1) Sat Binmas telah melakukan penyuluhan terhadap warga terutama yang berkaitan dengan tindak pidana narkotika dan bahaya tentang penyalahgunaan narkoba.

2) Sat Intelkam telah melakukan deteksi dini tentang tindak pidana konvensional dengan menambah jumlah jaringan yang ada di wilayah hukum Polres Demak sehingga setiap kejadian dapat termonitor dengan melaporkan tindak pidana yang ada serta memberikan informasi yang akurat tentang kejadian yang ada. 
3) Sat Reskim khususnya resmob telah ikut membantu dalam ungkap kasus tindak pidana narkoba yang di temukan dalam jog yang terdapat shabu-shabu.

4) Sat Shabara meningkatkan patroli ke tempat-tempat yang merupakan daerah rawan peredaran narkotika di wilayah hukum Polres Demak sesuai dengan route yang telah ditentukan dengan kejadian yang telah di terima oleh SPKT, sehingga diharapkan dapat meminimalisir terjadinya Tindak Pidana Narkotika.

5. Kendala Dan Upaya Penerapan Kebijakan Penal Dan Non Penal Dalam Pencegahan Kejahatan Narkoba

\section{a. Kendala \\ Penerapan \\ Kebijakan Penal dan Non \\ Penal Dalam Pencegahan Kejahatan Narkoba}

Berdasarkan hasil penelitian, meskipun ancaman pidana yang berat pada tahapan putusan pengadilan, tetapi belum jua memberikan efek jera bagi beberapa bandar dan pengedar narkoba di Demak.

\section{b. Penegak Hukum}

Masalah kekurangan anggota dalam upaya penanggulangan tindak pidana narkotika serta kurangnya prasarana penunjang dalam melaksanakan fungsi pengawasan di wilayah Demak merupakan kendala yang dihadapi aparat penegak hukum dalam pencegahan dan pengawasan terhadap peredaran narkoba di jalur laut.

Kendala yang lainnya adalah penyelidikan dilakukan secara manual atau menggunakan jasa informan dan tidak tersedianya alat pendeteksi komunikasi yang bisa mengetahui jaringan para pengedar narkoba, kurangnya personil Sat Resnarkoba yang secara DSP sebanyak 25 orang namun secara riil atau dilapangan jumlah personil Setresnarkoba Polres Demak hanya sebanyak 14 (empat belas) orang maka perlu dilakukan penambahan.

\section{c. Faktor masyarakat}

Kendala yang dihadapi adanya trend kenaikan tindak pidana narkotika adalah dikarenakan semakin meningkatnya tindak pidana narkotika yang dilakukan oleh para pelajar atau mahasiswa yang ada di wilayah Polres Demak. Selain itu faktor lain yang mempengaruhi adalah kurangnya kepedulian masyarakat untuk melaporkan apabila melihat kejadian tindak pidana narkoba serta kurang mengertinya tentang bahaya yang ditimbulkan akibat dari perbuatan penyalahgunaan narkoba.

\section{d. Sarana dan Prasarana}

Sarana dan prasana di satresnarkoba polres demak bisa dikatakan kurang memadai. Sarana dan prasarana untuk menunjang kinerja personil Satresnarkoba perlu ditambah seperti Ranmor R.2 maupun R.4 dinas serta sarana lainnya seperti alat screen test dan lain sebagainya yang sampai saat ini masih swadaya.

\section{Upaya dalam Penerapan Kebijakan Penal dan Non Penal Dalam Pencegahan Kejahatan Narkoba}

Berdasarkan data ungkap kasus pun Satresnarkoba Polres Demak telah mengungkap sebanyak 37 kasus. Apabila dibandingkan dengan tahun 2016 yang hanya mengungkap sebanyak 30 kasus, sehingga pada 
Tahun 2017 sudah ada kenaikan sebesar $23 \%$.

Sarana non penal dalam penanggulangan tindak pidana narkotika dilakukan dengan pendekatan advokasi bagi para tokoh masyarakat yang ada di setiap desa di Demak. Para tokoh masyarakat bekerja sama dengan tokoh pemuda bahkan pemuda-pemudi di Demak mereka dalam beberapa pertemuan yang rutin dilakukan untuk mengevaluasi program penanggulangan narkotika di wilayah masing-masing. Selain itu juga, dari akademisi hukum rutin melakukan kegiatan sosialisasi dan edukasi kepada masyarakat khususnya siswa-siswi baik SMP maupun SMA yang ada di kota Demak.

Upaya lain dengan mengoptimalkan ruang konsultasi penyalahgunaan narkoba yang ada di satres narkoba polres demak. Adanya ruang konsultasi tersebut diharapkan mampu mendorong turunnya angka penyalahgunaan narkotika di wilayah demak. Adapun ruang konsultasi tersebut bertujuan agar kalangan terdekat dari pengguna narkotika tidak ikut terpapar atau tergoda untuk turut menjadi pengguna narkotika.

Alternatif lain yang menjadi solusi untuk pencegahan tindak pidana narkotika adalah dengan dibukanya akun instagram @ satres_narkoba demak di media sosial. Akun tersebut menjadi jembatan bagi masyarakat untuk mengetahui aktifitas Sat resnarkoba Polres Demak dalam mencegah sekaligus menindak tindak pidana narkotika.

\section{Kesimpulan}

Optimalisasi kebijakan integral dalam penanggulangan tindak pidana anrkotika di Kabupaten Demak dilakukan dengan cara menggunakan integrasi kebijakan penggunaan sarana penal dan sarana non penal. Sarana penal dilakukan sesuai dengan petunjuk dan perintah dari UU nomer 35 tahun 2009 tentang narkotika, sehingga menjadikan hokum pidana sebagai senjata untuk memberantas tindak pidana narkotika.

Sementara sarana non penal pun turut digunakan sebagai langkah pencegahan kenaikan angka ungkap kasus tindak pidana narkotika di demak. Tindakan pencegahan tersebut meliputi penyuluhan di sekolah, turut bekerja sama dengan tokoh masyarakat sebagai bentuk partisipasi masyarakat. Adapun kendala yang dihadapi adalah sarana prasarana yang masih dirasa kurang memadai dan keterbatasan personil sehingga berdampak pada kinerja satres narkoba demak. Upaya yang dapat dilakukan adalah dengan terus mengintensifkkan ruang konsultasi narkoba di polres demak serta terus mengkampanyekan anti narkoba melalui media social dan penyuluhan.

\section{Saran}

a. Untuk pihak legislatif, perlunya Pasal baru dari segi UndangUndang Narkotika untuk penjatuhan pidana terhadap pelaku narkotika jenis baru.

b. Untuk pihak eksekutif, perlunya peningkatan kualitas penyidik Polri khususnya pada Direktorat Narkoba, dan peningkatan anggaran penyelidikan dan penyidikan kasus Narkotika, peningkatan sarana dan prasarana pendukung.

c. Kepada masyarakat, sudah jelas didalam Undang-Undang sudah 
dijelaskan masyarakat harus berperan aktif dalam membantu aparat penegak hukum dalam ungkap kasus.

\section{DAFTAR PUSTAKA}

Dwidja Priyanto, Sistem Pelaksanaan Pidana Penjara Di Indonesia, Refika Aditama, 2006

H. Zainuddin Ali, Metode Penelitian hukum, Sinar Grafika, 2010, Jakarta
Peter dan Yenny,, Kamus Bahasa Indonesia Kontemporer, Modern English Press, Jakarta, 2011.

Satuan Reserse Narkoba Polres Demak. 2018. Polres Demak.

Setiono, 2015, Rule of Law (Supremasi Hukum), Magister Ilmu Hukum Program Pascasarjana Universitas Sebelas Maret, Surakarta.

Soerjono Soekanto, 2016, Pengantar Penelitian Hukum, UI Press, Jakarta. 